\title{
Hoary Bat Parturition Date
}

By Robert W. Nero, Saskatchewan Museum of Natural Histcry

Actual birth dates for free-living mammals are seldom noted. It therefore gives me pleasure to record a birth date for young of the Hoary Bat (Lasiurus ciner:us). I am indebted for this information to Leslie Kirk, son of Mr. H. R. Kirk, Box 82, Plenty, Saskatchewan, who contacted me while I was in the vicinity on a field trip with Richard Fyfe and Fred Lahrman. An adult Hoary Bat was found by Leslie on June 22 , 1958, hanging in a caragana hedge at his home one mile south of Hood. It was kept in captivity and gave birth to two young on June 24 . One was born in the morning, the other about 8:00 p.m. This birth date fits well with the established data: according to W. $\mathrm{H}$. Burt (NIammals of Michigan. 1946, Ann Arbor) two young are born in June; W. H. Hamilton, Jr. (Mammals of Eastern United States. 1943, Ithaca) states that birth occurs near the middle of June; and V. Bailey (Biol. Survey N. Dakota. 1946, North American Fauna, No. 49) lists specimens collected on June 12, 1883 , and June 20, 1913, both containing two large embryos. A specimen collected by F. G. Bard at Simpson, Saskatchewan, on June 8, 1930, contained two well-developed embryos.

Actual birth of the second young was observed by Leslie and some relatives. Birth occurred with the parent hanging upside down. They noticed that the parent licked the newborn young while remaining "all doubled up". They also observed the older young being transferred from the parent's back (where it had apparently managed to crawl or been placed) to the abdominal region. The parent used one hind foot to effect this transfer. When first observed by myself on June 25, both young had their mouths attached to the anterior set of mammary glands and were tightly clasped within the folded wings and furred interfemoral membrane of the adult.

We returned the next day to transport the bats with us to the Museum. Probably owing to a lack of proper diet, all had succumbed by the following day, which was un fortunate, since $I$ was anxious $t$ raise the young.

The Hoary Bat is the largest ba found in Saskatchewan. (This adul had a wingspread of $16^{1 / 2}$ inches. Its colour is generally pale golden. brown with white tips on the hair which give it a hoary appearance from which the name is derived The throat and head region ar rather yellowish. The young bat described above had a coating o pale silvery - grey hair on the back, covering as well the hind fee and forehead, but they were other wise hairless and blind. Both stil retain $€ d$ umbilical cords when the: died. Measurements of the youn and parent bat are given below ti indicate their relative size and pro portions.

Measurements in $\mathrm{mm}$. of adult Hoary $\mathrm{Ba}$ and young (two days old).

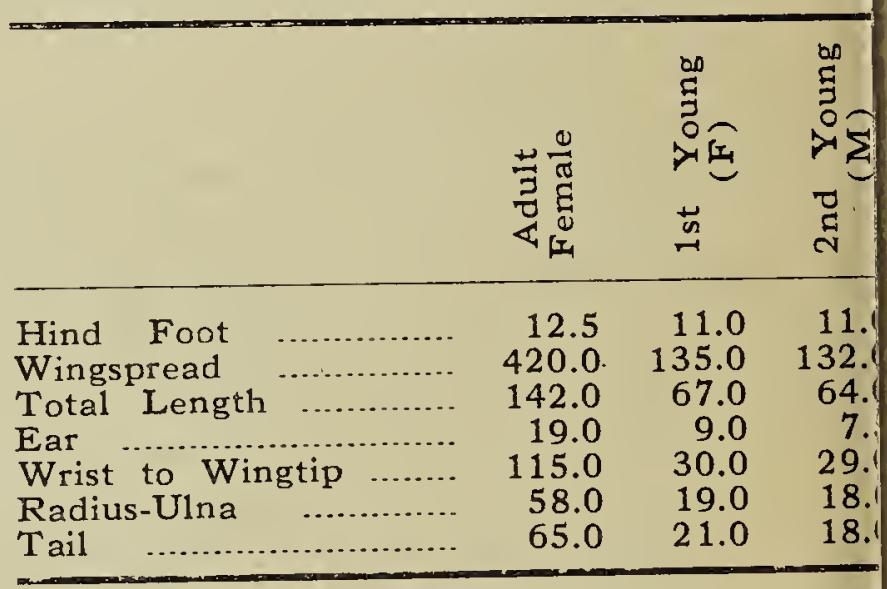

Note the disproportion betweer the wing lengths. The wings of th young bats are relatively poorl: developed at this stage compared with the hind feet which are nearly adult size. Obviously, since the young bats need to cling to the parent (which is said to carry then about until nearly full-grown) and to hang upside down, the welldeveloped hind feet are a definit advantage. Newly-born Opossum: (Didelphis virginiana), which need to crawl from the vaginal orifice $t$ the marsupium, on, the other hand exhibit well-developed fore-feet a: soon as born, although they art otherwise quit'e premature. The pale or unpigmented area of the adul wing membrane is also apparent ir the young bats, though in the lattes the relative size of pigmented anc 
unpigmented areas is reversed, again indicating the greatest area of future development.

The Hoary Bat is a sclitary species which probably occurs uncommonly throughout most of the province, but particularly in the forested regions. Like other bats, it is believed to migrate south for the winter. Additional information concerning the distribution and habits of this and other species of bats is always welcomed. Bats may be shipped alive to the Museum in a perforated box, or dead bats may be sent preserved in alcohol.

\section{Experiences With Orphan Fawns}

\section{By Dave Santy, Beechy}

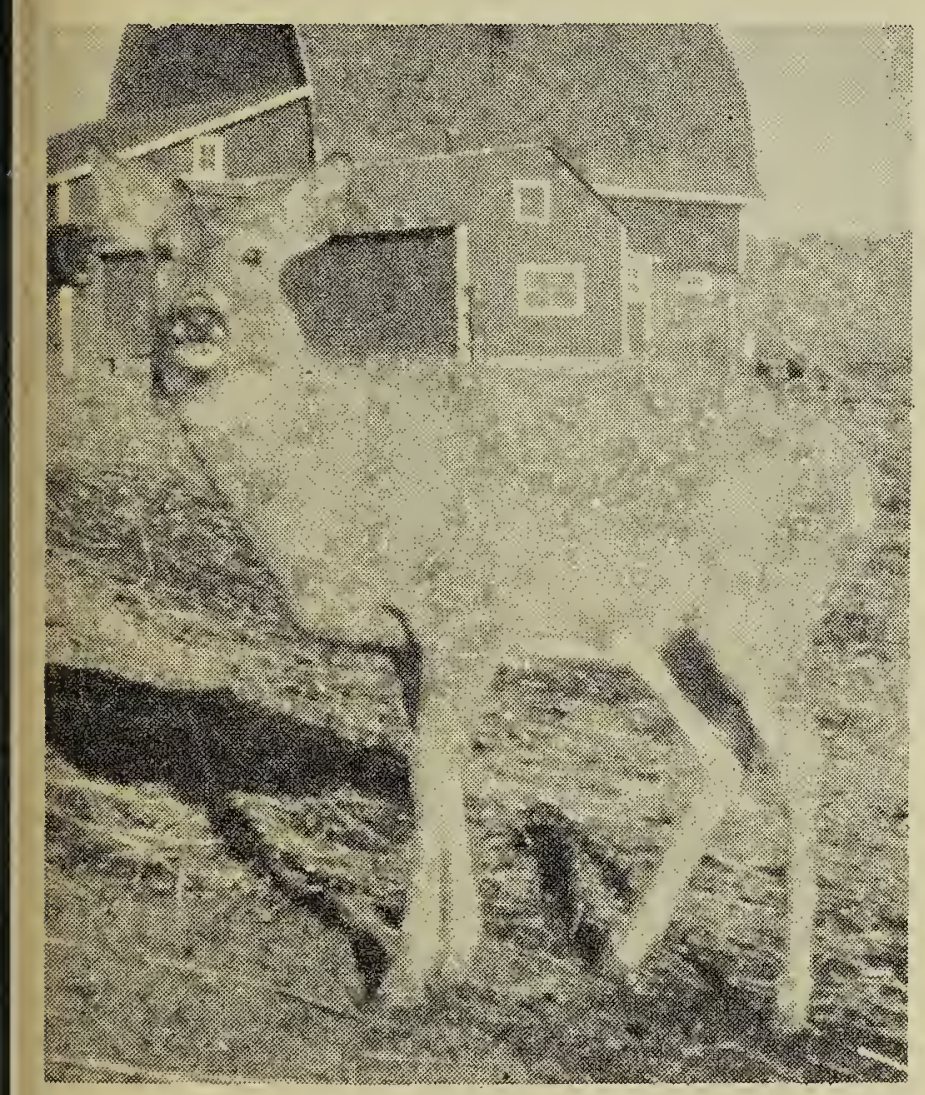

Picture by Dennis Treslan

The Galbraith deer at two years of age.

Mr. Jack Link, of Beechy, is a commuting farmer. Three years ago on a bright spring morning, he arrived at the farm, about eight miles south of Beechy, and saw a fawn stumbling weakly over a summerfallow field. He went toward the little fellow, who was in such a weakened condition that he showed no signs of alarm. Jack, satisfied that the fawn had strayed from its mother or that something had happened to the matron, lifted it into the truck cab and took it home. The family immediately went to work trying to give it nourishment and before long had the waif taking quite kindly to the baby bottle.

In a few days the fawn came to be decidedly demanding of attention. He was being housed in the grain box of the big truck, but since this would not hold him long the family had to give consideration to making proper disposition of him. They contacted the Game Branch at Regina. By favourable coincidence, the Branch had just received a request from $\mathrm{Mr}$. and Mrs. Nyholt of North Battleford for authority to try and get a young deer. The Department forthwith sent a letter of authority to those good folks to take possession of "Bambi". Nor did the Nyholts lose any time in doing so. They came to Beechy immediately.

Mr. and Mrs. Nyholt, at their Golden Gate Wildlife Farm, have various. forms of domesticated wildlife. These wild animals and their numerous ponies are a big attraction to their visitors.

In a letter from $\mathrm{Mr}$. and Mrs. Nyholt written to them last Christmas, Mr. and Mrs. Link learned that Bambi has grown to be a majestic specimen of deerhood and that he now has a suitable mate on which he lavishes every attention.

Almost simultaneously with $\mathrm{Mr}$. Link's finding the little fawn, $\mathrm{Mr}$. E. Bowman and his son-in-law Pat Galbraith, ranchers and farmers, were fixing fence in a field adjoining the Links' summerfallow and they too came across a young and very weak fawn. They left it there until they found a dead doe fresh in milk a short distance down the fence line. They considered it a family tragedy and Pat took the little fawn home. He responded well to the bottle feeding and kindly treatment of Mrs. Galbraith. It was not until months later that Mr. Link and Mr. Galbraith learned of the coincidence of their finds and concluded that the two fawns were of the same family. 